\title{
Pengaruh jumlah uang beredar dan tingkat suku bunga serta pengeluaran pemerintah terhadap inflasi di indonesia
}

\author{
Nuri Agusmianata $^{1}$, Theresia Militina ${ }^{2}$ Diana Lestari $^{3}$ \\ Fakultas Ekonomi dan Bisnis Universitas Mulawarman, Samarinda \\ ${ }^{1}$ Email: nuriasaputra@gmail.com \\ ${ }^{2}$ Email: theresia.militina@feb.unmul.ac.id \\ ${ }^{3}$ Email: diana.lestari@feb.unmul.ac.id
}

\begin{abstract}
Abstrak
Pengaruh Pemberian Uang dan Suku Bunga dan Belanja Pemerintah terhadap Inflasi di Indonesia. Penelitian ini bertujuan untuk mengetahui pengaruh jumlah uang beredar, suku bunga dan pengeluaran pemerintah terhadap inflasi di Indonesia. Teori menggunakan teori Irving Fisher, teori Gibson Paradox dan teori Keynes. Penelitian ini dilakukan dengan menggunakan alat analisis regresi linier berganda fungsi Cobb-Douglas. Uji hipotesis menggunakan uji t dan uji F digunakan untuk mengetahui kelayakan model. Analisis tersebut menunjukkan adanya pengaruh signifikan dari jumlah uang beredar terhadap inflasi, tingkat suku bunga berpengaruh signifikan terhadap inflasi dan pengeluaran pemerintah berpengaruh signifikan terhadap inflasi. Pasokan uang mempengaruhi sebagian besar inflasi di Indonesia.

Kata Kunci: Uang Beredar; Suku Bunga; Belanja Pemerintah dan Inflasi

\section{Influence of money supply and interest rate and government expenditure on inflation in indonesia}

Abstract

Effect of Money Supply and Interest Rates and Government Expenditures to Inflation in Indonesia. This study aims to determine the effect of the money supply, interest rates and government expenditures to inflation in Indonesia. Theory used the theory of Irving Fisher, Gibson Paradox theory and the theory of Keynes. The study was conducted by using multiple linear regression analysis tool Cobb-Douglas function. Hypothesis testing using $t$ test and $F$ test is used to determine the feasibility of the model. The analysis revealed a significant effect of money supply on inflation, interest rates have a significant effect on inflation and government expenditures significant effect on inflation. The money supply affects most to inflation in Indonesia.
\end{abstract}

Keywords: Money Supply; Interest Rates; Government Expenditures and Inflation 


\section{PENDAHULUAN}

Inflasi merupakan masalah yang menghantui perekonomian setiap negara. perkembangan yang terus meningkat memberikan hambatan pada pertumbuhan ekonomi ke arah yang lebih baik. Pembangunan ekonomi adalah suatu usaha untuk meningkatkan taraf hidup masyarakat yang seringkali diukur melalui tinggi rendahnya pendapatan penduduk tiap tahunnya atau pendapatan perkapita.

Hampir semua negara baik negara yang maju maupun negara yang sedang berkembang mangalami kestabilan serta masalah pertumbuhan ekonominya. Indonesia sebagai salah satu negara yang sedang berkembang di mana kehidupan ekonominya sangat tergantung pada tata moneter dan perekonomian dunia, selalu menghadapi masalah masalah tersebut. Pertumbuhan ekonomi Indonesia dalam beberapa dasawarsa ini sangat terpuruk dan ini dibarengi dengan semakin terintegritasnya ekonomi indonesia dengan ekonomi dunia.

Teori Paradox Gibson menjelaskan bahwa kecenderungan harga dan tingkat suku bunga bergerak bersama. Jika harga naik, tingkat suku bunga cenderung naik dan jika harga turun, tingkat suku bunga cenderung turun juga (Iswardono, 1999: 246). Teori ini sesuai dengan penelitian terdahulu oleh Adrian dan Zulfahmi (2012) yang berjudul Pengaruh Faktor - Faktor Ekonomi Terhadap Inflasi di Indonesia.

Sedangkan hal-hal yang menyangkut kebijakan fiskal yaitu kebijakan di bidang Anggaran Pendapatan dan Belanja Negara (APBN). Peran pemerintah dalam hal ini sangat penting terhadap pengendalian jumlah uang beredar dan hubungannya terhadap laju inflasi, sehingga diharapkan adanya anggaran yang berimbang yaitu pengeluaran dan penerimaan sama. Tabungan pemerintah diusahakan mengalami peningkatan, objek pajak di perluas, memperiotaskan pengeluaran hanya pada bidang yang produktif. Pengeluaran dibatasi dan kebijakan ditujukan untuk pemanfaatan sumber daya alam dan sumber daya manusia yang potensial, sehingga dapat meningkatkan pendapatan nasional dan menekankan laju inflasi.

Secara spesifik, Keynes yakin pemerintah memotong pajak atau menaikkan pengeluarannya yang disebut kebijakan fiskal ekspansioner untuk mengeluarkan perekonomian dari penuruan. Sebaliknya, Keynes mengemukakan bahwa pemerintah hendaknya menaikkan pajak atau mengurangi pengeluarannya yang disebut kebijakan fiskal kontraksioner untuk mengeluarkan perekonomian dari inflasi (Case \& Fair, 1999: 8).

Inflasi yang berlangsung lama akan melumpuhkan perekonomian, pertumbuhan ekonomi menjadi semakin lesu karena industri dan produksi berada dalam kondisi stagnan. Keadaan seperti ini dalam ilmu ekonomi di sebut stagnasi.

Tabel 1. Data Jumlah Uang Beredar, Tingkat Suku Bunga, Pengeluaran Pemerintah dan Inflasi Tahun 2006 - 2015 di Indonesia

\begin{tabular}{ccccc}
\hline Tahun & $\begin{array}{c}\text { Jumlah Uang Beredar (M2) } \\
\text { Milyar Rupiah }\end{array}$ & $\begin{array}{c}\text { Tingkat Suku } \\
\text { Bunga } \\
\text { BI Rate (\%) }\end{array}$ & $\begin{array}{c}\text { Pengeluaran } \\
\text { Pemerintah } \\
\text { Milyar Rupiah }\end{array}$ & $\begin{array}{c}\text { Inflasi } \\
(\%)\end{array}$ \\
\hline 2006 & 1.382 .493 & 9,75 & 440,032 & 6,60 \\
2007 & 1.649 .662 & 8 & 504,623 & 6,59 \\
2008 & 1.895 .839 & 9,25 & 693,335 & 11,06 \\
2009 & 2.130 .383 & 6,5 & 628,812 & 2,78 \\
2010 & 2.471 .205 & 6,5 & 697,407 & 6,96 \\
2011 & 2.877 .219 & 6 & 883,722 & 3,79 \\
2012 & 3.307 .577 & 5,75 & $1,010,558$ & 4,30 \\
2013 & 3.730 .409 & 7,5 & $1,137,163$ & 8,38 \\
2014 & 4.173 .326 & 7,75 & $1,203,577$ & 8,36 \\
2015 & 4.548 .800 & 7,50 & $1,183,304$ & 3,35 \\
\hline
\end{tabular}

Sumber: Bank Indonesia dan Badan Pusat Statistik (BPS) Indonesia

Tabel 1 tersebut menunjukan jumlah uang beredar, tingkat suku bunga, pengeluaran pemerintah dan inflasi di Indonesia cenderung mengalami siklus naik turun. Pada tahun 2006 - 2015 jumlah uang beredar mengalami kenaikan setiap tahunnya, pada tahun 2006 tingkat suku bunga sebesar $9,75 \%$ dan kemudian mengalami penurunan pada tahun 2012 sebesar 5,75, pada tahun 2008 pengeluaran pemerintah sebesar 693,335 Milyar Rupiah dan mengalami penurunan pada tahun 2009 sebesar 628,812 
Milyar Rupiah, dan pada tahun 2008 inflasi mengalami kenaikan sebesar 11,06\% kemudian turun derastis pada tahun 2009 sebesar $2,78 \%$.

Berdasarkan kesimpulan permasalahan yang telah diuraikan, maka peneliti mengambil judul "Pengaruh Jumlah Uang Beredar dan Tingkat Suku Bunga serta Pengeluaran Pemerintah Terhadap Inflasi di Indonesia".

\section{TINJAUAN PUSTAKA}

\section{Inflasi}

Inflasi merupakan fenomena moneter yang merupakan suatu proses kenaikan harga yaitu adanya kecendrungan bahwa harga meningkat secara terus menerus. Ini tidak berarti bahwa harga-harga berbagai macam barang itu naik dengan persentase yang sama. Mungkin dapat terjadi kenaikan tersebut tidaklah bersamaan. Yang terpenting terdapat kenaikan harga umum barang secara terus menerus selama satu periode tertentu, kenaikan harga yang terjadi hanya sekali saja (meskipun dengan persentase yang cukup besar) bukanlah merupakan inflasi, kecuali tercermin dalam keadaan kelebihan permintaan akan uang (excess supply money). Sedangkan dari sektor rill, inflasi ditimbulkan oleh adanya permintaan akan barang terhadap penawarannya (excess demand for goods).

Inflasi adalah kecendrungan dari harga-harga untuk menarik secara umum dan terus - menerus (Boediono, 2005:155).

\section{Cara Mengukur Inflasi}

Banyak cara yang digunakan untuk mengukur tingkat Inflasi, diantaranya adalah dengan menggunakan (Waluyo, $2006: 168$ ) :

1. General Price

2. Angka Deflator Produk Nasional Bruto.

3. IHK (Indeks Harga Konsumen).

4. Atas Harga Yang Hiharapkan

5. Indeks Harga Dalam Negeri dan Luar Negeri.

\section{Inflasi Menurut Keynes}

Menurut teori ini, inflasi terjadi karena suatu masyarakat ingin hidup di luar batas kemampuan ekonominya sehingga proses inflasi merupakan proses perbuatan bagian rezeki antar golongan masyarakat untuk memperoleh bagian yang lebih besar daripada yang mampu disediakan oleh masyarakat itu sendiri yang berdampak terhadap permintaan barang dan jasa yang pada akhirnya akan menaikan harga. Proses perebutan ini disebut inflationary gap karena permintaan efektif barang-barang (permintaan agregat) melebihi jumlah output/barang yang tersedia (penawaran agregat). Keterbatasan jumlah persediaan barang terjadi karena dalam jangka pendek kapasitas produksi tidak dapat dikembangkan untuk mengimbangi kenaikan permintaan agregat (Boediono, 1995: 169).

Proses inflasi akan berlangsung terus selama permintaan efektif lebih besar dari jumlah output yang dihasilkan. Inflasi akan berhenti bila permintaan efektif tidak melebihi jumlah output yang tersedia pada harga-harga yang berlaku. Cara mengatasi inflasi seperti ini dengan meningkatkan jumlah output yang dihasilkan untuk mengantisipasi kelebihan permintaan yang terjadi. Permintaan masyarakat akan barang-barang selalu melebihi jumlah barang-barang yang tersedia (timbulnya demand full inflation).

\section{Inflasi Menurut Teori Strukturalis}

Dalam teori ini, inflasi sebenarnya disebabkan oleh ketegaran (inflexibility) dari struktur perekonomian. Struktur perekonomian yang tegar biasanya ditemukan di negara - negara yang sedang berkembang yang dapat berubah secara gradual dan dalam jangka panjang. Dua ketegaran utama dalam perekonomian yang dapat mengakibatkan inflasi adalah:

1. Ketidak - elastisan dari penerimaan ekspor.

2. Ketidak-elastisan dari supply bahan makanan di dalam negeri. 


\section{Inflasi Menurut Teori Kuantitas}

Teori ini mengatakan bahwa inflasi biasa terjadi kalau ada penambahan volume jumlah uang. Bila jumlah uang beredar tidak bertambah, inflasi akan berhenti dengan sendirinya, jadi penanggulangan inflasi bersumber pada penanggulangan jumlah uang beredar. Jumlah uang beredar bertambah, maka akan terjadi inflasi (kenaikan harga).

Laju inflasi ditentukan oleh laju pertambahan jumlah uang yang beredar dan oleh psikologi (harapan) masyarakat mengenai kenaikan harga di masa yang akan datang. Apabila masyarakat sudah beranggapan demikian, maka tidak ada kecenderungan untuk menyimpan uang tunai lagi dan mereka lebih suka menyimpan harta kekayaan dalam bentuk barang.

\section{Jenis Inflasi}

Parah tidaknya inflasi dapat digolongkan empat macam, yaitu :

1) Inflasi Ringan (Creeping Inflation)

Biasanya Creeping inflation ditandai dengan laju inflasi yang rendah (kurang dari 10\% per tahun). Mempunyai pengaruh yang positif dalam mendorong perekonomian untuk berkembang lebih baik yaitu meningkatkan pendapatan nasional dan membuat orang menjadi bergairah untuk bekerja, menabung maupun mengadakan investasi.

2) Inflasi Menengah (Galloping Inflation)

Ditandai dengan kenaikan harga yang cukup besar antara 10\% - 30\% setahun (dua sampai tiga digit) dan kadang-kadang berjalan dalam waktu yang relatif pendek serta mempunyai sifat akselerasi. Efeknya terhadap perekonomian lebih berat daripada inflasi yang merayap (creeping inflation).

3) Inflasi Berat

Inflasi berat, jika besarnya inflasi antara 30\% - 100\% setahun, pada kondisi demikian, perekonomian mulai lesu terutama pada sektor-sektor industri.

4) Inflasi Sangat Berat

Inflasi sangat berat (hyper inflation), jika inflasi lebih dari $100 \%$ keadaan perekonomian menjadi kacau balau, dan perekonomian menjadi lesu.

\section{Faktor-faktor terjadinya inflasi}

Berdasarkan kepada sumber atau penyebab kenaikan harga - harga yang berlaku, inflasi biasanya dibedakan kepada tiga bentuk berikut (Sukirno, 2008: 333) :

1) Inflasi tarikan permintaan (Demand Pull Inflation)

Inflasi ini biasanya terjadi pada masa perekonomian berkembang dengan pesat. Kesempatan kerja yang tinggi menciptakan tingkat pendapatan yang tinggi dan selanjutnya menimbulkan pengeluaran yang melebihi kemampuan ekonomi mengeluarkan barang dan jasa. Pengeluaran yang berlebihan ini akan menimbulkan inflasi.

2) Inflasi desakan biaya (Cost Push Inflation)

Inflasi ini terutama berlaku dalam masa perekonomian berkembang dengan pesat ketika tingkat pengangguran adalah sangat rendah. Apabila perusahan - perusahan masih menghadapi permintaan yang bertambah, mereka akan berusaha menaikan produksi dengan cara memberikan gaji dan upah yang lebih tinggi kepada pekerja dan mencari pekerja baru dengan tawaran pembayaran yang lebih tinggi ini. Langkah ini mengakibatkan biaya produksi meningkat, yang akhirnya akan menyebabkan kenaikan harga - harga berbagai barang.

3) Inflasi diimpor

Inflasi dapat juga bersumber dari kenaikan harga - harga barang yang di impor. Inflasi ini akan wujud apabila impor yang mengalami kenaikan harga mempunyai peranan penting dalam kegiatan pengeluaran perusahan - perusahaan.

\section{Kebijaksanaan - Kebijaksanaan Mengatasi Inflasi}

Telah kita ketahui bahwa inflasi adalah suatu proses di mana nilai uang semakin turun. Dengan demikian jelas bahwa kebijaksanaan untuk mengatasi inflasi harus dihubungkan dengan usaha meniadakan faktor-faktor yang menyebabkan perubahan nilai. Untuk itu ada tiga kebijaksanaan yang bisa di tempuh, yakni : 
1) Kebijaksanaan Moneter

2) Kebijaksanaan Fiskal

3) Kebijaksanaan Non Moneter-Fiskal

\section{Macam-macam Uang}

1. Uang Kartal

Uang kartal adalah uang tunai kertas dan logam yang di keluarkan bank central di pegang oleh masyarakat non-bank.

2. Uang Giral

Uang giral adalah uang saldo simpanan pada bank - bank pencipta uang giral yang setiap saat dapat di tarik untuk di tukarkan dengan uang kartal sebesar jumlah nominalnya dan tidak dikenakan penalty.

Contoh : Saldo rekening, rekening koran, transfer, dll.

3. Uang Kuasi

Uang kuasi adalah surat atau sertifikat berharga yang dapat dijadikan sebagai alat pembayaran yang sah, akan tetapi tidak liquid. Fungsi yang tidak sepenuhnya adalah fungsi alat tukar menukar.

Contoh : Deposito berjangka rupiah, sertifikat deposito, tabungan berjangka, rekening giro dalam valuta asing, dll.

\section{Teori Permintaan Uang}

Teori permintaan uang (moneter) kaum klasik yang dikemukakan oleh Irving Fisher ini dapat dirumuskan :

$M V=P T($ Mulia Nasution, $2001: 44)$

Dimana:

$\mathrm{M}=$ Jumlah uang yang beredar

$\mathrm{V}=$ Perputaran pada perekonomian dalam satu periode

$\mathrm{P}=$ Tingkat harga barang

$\mathrm{T}=$ Volume barang dan jasa yang di perdagangkan dalam satu periode

Pada persamaan diatas $\mathrm{M}$ diartikan dengan pengertian uang yang beredar, yaitu uang kertas, uang logam dan uang giral yang terdapat di dalam perekonomian, $\mathrm{V}$ merupakan besarnya laju peredaran uang, ini ditentukan seringnya uang berpindah tangan dari seseorang ke orang lain dalam masyarakat selama satu tahun, dan $\mathrm{T}$ banyaknya barang dan jasa yang di perdagangkan dalam perekonomian pada satu periode.

Persamaan di atas dapat diketahui, jumlah uang yang di terima penjual sama dengan yang dibayarkan pembeli. Ini berlaku untuk seluruh perekonomian, nilai barang dan jasa yang terjual harus sama dengan barang yang dibeli dalam jangka periode tertentu. Nilai barang dan jasa yang terjual sama dengan volume transaksi (V) dikalikan harga rata-rata barang dan jasa tersebut. Disisi lainnya nilai barang dan jasa yang di perjual belikan harus sama pula dengan volume jumlah uang yang beredar di tangan masyarakat $(\mathrm{M})$ dikalikan rata-rata uang berpindah tangan dari tangan yang satu ke tangan yang lainnya atau laju perputaran dalam periode yang bersangkutan (VT) sehingga rumus di atas dapat diubah menjadi :

$\mathrm{MV}_{\mathrm{T}}=\mathrm{PT}$

$\mathrm{V}_{\mathrm{T}}$ adalah laju kecepatan perputaran transaksi (transaction velocity of circulation) merupakan variabel yang dipengaruhi (ditentukan) faktor-faktor lembaga yang ada dalam masyarakat, dan dianggap tetap dalam jangka pendek. $\mathrm{T}$ (volume transaction) sangat ditentukan oleh pendapatan nasional (output dalam masyarakat), ini mempunyai nilai tertentu dalam satu tahun. Persamaan di atas bisa dirumuskan dalam permintaan uang, yaitu :

$\mathrm{Md}=\underline{\mathrm{PT}}$

Karena volume transaksi dan harga yang terjadi dianggap konstan (PT tetap), maka keseimbangan moneter dapat diketahui, yaitu :

$\mathrm{Md}=\mathrm{Ms}$

Dimana Ms = penawaran uamg yang beredar sehingga menghasilkan : 
$\mathrm{Ms}=\frac{P T}{V T}$

Persamaan di atas dapat diartikan dalam jangka pendek variabel P (harga umum) akan berubah secara proporsional dengan adanya perubahan uang yang beredar. T ditentukan oleh tingkat output equilibrium masyarakat.

Variabel Vt (V dianggap konstan dalam jangka pendek) ini ditentukan oleh:

1) Bentuk transaksi yang terjadi dalam masyarakat

2) Sistem lembaga yang terjadi dalam perekonomian

3) Bilamana dalam perekonomian terjadi pemberian perdagangan dengan sistem kredit, sehingga kebutuhan uang akan menurun.

Implikasi dari teori moneter dari Fisher adalah sebagai berikut :

1) Permintaan akan uang di dalam suatu masyarakat merupakan proporsi tertentu dari volume transaksi, dan volume transaksi merupakan suatu proporsi konstan pula dari tingkat output masyarakat (pendapatan nasional). Jadi permintaan akan uang pada analisa akhir ditentukan oleh tingkat pendapatan nasional saja, dan tidak dipengaruhi oleh faktor-faktor lain seperti tingkat bunga.

2) Dari segi kebijaksanaan ekonomi makro, teori moneter ini mempunyai implikasi yang penting, yaitu bahwa tingkat pendapatan nasioanal equilibrium, atau tingkat harga umum bila tingkat full employment sudah tercapai, tidak bisa dipengaruhi oleh kebijaksaan fiskal.

\section{Teori Penawaran Uang}

Penawaran uang adalah salah satu unsur yang penting untuk mencapai suatu keseimbangan pasar secara keseluruhan.

Keynes menjabarkan pandangannya tentang bagaimana tingkat bunga ditentukan dalam jangka pendek. Untuk mengembangkan teori ini, kita mulai dengan penawaran keseimbangan uang rill. Jika $\mathrm{M}$ menyatakan jumlah uang beredar dan $\mathrm{P}$ menyatakan tingkat harga, maka M/P adalah panawaran keseimbangan uang rill (Mankiw, $2003: 265$ ).

Berdasarkan pengertian diatas dapat disimpulkan bahma teori permintaan uang dikembangkan oleh para ahli ekonomi, orang belum banyak mempersoalkan teori penawaran uang oleh karena dianggap hal tersebut bisa dilakukan oleh penguasa moneter khususnya bank sentral di negara tersebut. Cara penguasa meneter untuk bisa menetapkan jumlah uang beredar adalah dengan menerapkan rasio cadangan bank-bank umum dan uang kartal.

Penawaran uang / MS adalah jumlah uang yang tersedia dalam suatu perekonomian atau keseluruhan uang yang diedarkan bank pada waktu tertentu. Definisi MS dapat dilihat sebagai berikut (Rosyidi, 2005:281):

a) M0, yaitu definisi MS secara sempit. M0 hanya terdiri dari uang kertas dan uang logam yang kita pegang sehari-hari yang tidak dipegang oleh bank maupun pemerintah.

b) M1 adalah M0 ditambah simpanan dalam bentuk rekening koran atau demand deposit. Demand deposit adalah tabungan yang kita miliki di bank yang dapat kita carikan sewaktu-waktu dan merupakan perhitungan jumlah uang beredar yang paling likuid.

c) M2 adalah M1 + tabungan + deposito berjangka (time deposit) dalam jumlah kecil pada bank-bank umum. Time deposit adalah tabungan, deposito dan sejenisnya yang memiliki waktu jatuh tempo atau tidak dapat dicairkan sewaktu-waktu.

d) M3 adalah M2 + deposito berjangka panjang dalam jumlah besar pada lembaga-lembaga tabungan non bank. Ini meliputi dana-dana institusional yang ada dipasar uang.

M1 adalah yang paling liquid karena proses menjadikannya uang kas sangat cepat. Sedangkan M2 karena mencakup deposito berjangka maka likuiditasnya lebih rendah. Untuk menjadikannya uang perlu waktu, dan apabila dijadikan uang kas sebelum jangka waktu tersebut akan terkena denda.

\section{Tingkat Suku Bunga}

Interest rate atau bunga uang adalah variabel ekonomi yang sering kita jumpai dalam setiap kebijakan ekonomi dan mempunyai efek yang besar dalam mempengaruhi variabel ekonomi lainnya (Taufik, 2002 : 21). Contohnya dapat kita lihat dalam pasar saham bahwa keputusan untuk membeli dan menjual sangat terpengaruh dengan keputusan bank central untuk menaikan atau menurunkan tingkat 
bunga, selain itu dalam tingkat perusahaan ataupun rumah tangga dan pemerintah keputusan untuk menjamin juga sangat dipengaruhi oleh rate suku bunga ini.

Menurut Krugman dan Obstfeld, (1999:30), dalam ilmu ekonomi ada perbedaan yang penting antar suku bunga nominal (nominal interest rate) yaitu tingkat imbalan (Rate Of Return) dalam satuan moneter dengan suku bunga rill (Real Interest Rate) yaitu tingkat imbalan secara rill atau yang dinyatakan dalam satuan output suatu negara. Mengingat suku bunga rill seringkali tidak pasti, maka ia biasanya disebut perkiraan suku bunga rill.

Tingkat suku bunga merupakan biaya alternatif dari penggunaan modal apabila pengusaha meminjam modal dari bank, namun yang penting bagi pengusaha bukanlah tingkat bunga dalam arti nominal (seperti yang tertera dibank) tetapi dalam arti rill. Menurut Nopirin, (2002:12), tingkat bunga rill adalah tingkat bunga nominal dikurangi dengan inflasi.

\section{Teori Paradox Gibson}

Teori Paradox Gibson menjelaskan bahwa terdapat bukti empiris tentang kecenderungan harga dan tingkat suku bunga bergerak bersama. Jika harga naik, tingkat suku bunga cenderung naik dan jika harga turun, tingkat suku bunga cenderung turun juga (Iswardono, 1999: 246).

Kalau perubahan harga diantisipasikan, artinya masyarakat segera berantisipasi terhadap apa yang terjadi, maka tingkat suku bunga yang tinggi akan dikaitkan dengan laju inflasi yang cepat. Akan tetapi tidak ada alasan untuk mengharapkan adanya hubungan positif antara tingkat suku bunga dengan kenaikan laju inflasi, dan sebaliknya penurunan tingkat suku bunga dengan penurunan laju inflasi. Menurut Gibson Paradox, kenaikan harga dikaitkan dengan kenaikan tingkat suku bunga dan penurunan harga dikaitkan dengan penurunan tingkat suku bunga. Untuk lebih jelasnya Fisher mengatakan bahwa kalau harga mulai meningkat masyarakat diharapkan jangan percaya. Hal ini di sebabkan karena akan memerlukan waktu yang lama sebelum menerima kenyataan bahwa kenaikan harga akan meningkatkan tingkat suku bunga. Antisipasi perubahan harga mulai dari lambat dan secara gradual saja, dan setelah tenggang waktu akan mulai menurun dan menurun lagi secara gradual. Sehingga oleh Fisher dikatakan, biarkan harga mulai meningkat karena peningkatan harga tersebut akan stabil. Baru setelah itu masyarakat berantisipasi terhadap kenaikan harga (Iswardono, 1999: 252).

\section{Pengeluaran Pemerintah}

Pengeluaran pemerintah merupakan salah satu komponen kebijakan fiscal yang bertujuan untuk laju inflasi, meningkatkan kesempatan kerja, memelihara kestabilan ekonomi dan menciptakan distribusi pendapatan yang merata melalui belanja Negara baik itu belanja rutin maupun belanjaa pembangunan.

Menurut Basri dan Subri (2003), Pengeluaran pemerintah itu sangat bervariasi, namun secara garis besarnya dapat diklasifikasikan sebagai berikut:

1) Pengeluaran yang merupakan investasi yang menambah kekuatan dan ketahanan ekonomi dimasa yang akan datang.

2) Pengeluaran yang langsung memberikan kesejahteraan dan kemakmuran masyarakat.

3) Pengeluaran yang merupakan penghematan terhadap masa yang akan datang. Pengeluaran untuk menyediakan kesempatan kerja yang lebih luas dan menyebarkan daya beli yang luas.

Pengeluaran pemerintah berperan dalam untuk mempertemukan antara permintaan masyarakat dengan penyediaan sarana dan prasarana yang tidak dapat di penuhi oleh swasta. Pengeluaran pemerintah yang terus berkembang mengakibatkan penerimaan Negara harus ditingkatkan. Hal ini berarti bahwa pemerintah harus dapat menggali sumber-sumber penerimaan yang sebagian besar berasal dari pajak.

Walaupun secara keseluruhan pengeluaran pemerintah sangat penting dalam sumbangannya terhadap pendapatan nasional, tetapi yang lebih penting lagi adalah penentuan komposisi dari pengeluaran pemerintah tersebut. Komposisi dari pengeluaran pemerintah merupakan strategi untuk mencapai sasaran dari pembangunan nasional. 


\section{Teori Keynes}

Keynes berpendapat system pasar bebas tidak akan dapat membuat penyesuaian - penyesuaian yang akan menciptakan tingkat kesempatan kerja penuh. Untuk mencapai keadaan itu diperlukan kebijakan - kebijakan pemerintah. Di samping berusaha untuk mencapai tingkat kesempatan kerja penuh, kebijakan pemerintah perlu pula untuk: (i) menstabilkan tingkat harga dan mencegah inflasi, (ii) mengukuhkan pertumbuhan ekonomi, dan (iii) menjaga kestabilan sektor luar negeri.

Tiga bentuk kebijakan pemerintah dapat digunakan untuk mencapai tujuan - tujuan kebijakan makro ekonomi yang dinyatakan diatas: kebijakan fiscal, kebijakan moneter dan pengawasan langsung. Kebijakan fiscal dijalankan oleh Departemen Keuangan dan alat yang digunakan adalah melalui pengaturan anggaran pengeluaran dan penerimaan pemerintah (perpajakan). Dalam masa inflasi biasanya kebijakan fiscal akan berbentuk mengurangi pengeluaran pemerintah dan meningkatkan pajak (Sukirno, 2000: 20).

\section{Pengaruh Antara Variabel \\ Pengaruh Antara Jumlah Uang Beredar Terhadap Inflasi}

Teori Kuantitas menyatakan bahwa inflasi bisa terjadi kalau ada penambahan volume uang yang beredar (apakah berupa penambahan uang kartal atau penambahan uang giral tidak menjadi soal). Tanpa ada kenaikan jumlah uang yang beredar, kejadian seperti, misalnya, kegagalan panen, hanya akan menaikan harga-harga untuk sementara waktu saja. Penambahan jumlah uang ibarat "bahan-bakar" bagi api inflasi. Bila jumlah uang tidak ditambah, inflasi akan berhenti dengan sendirinya, apapun sebabmusababnya awal dari kenaikan harga tersebut ( Boediono, 1996: 167).

Para ahli ekonomi sepakat untuk menyatakan bahwa umumnya inflasi dipengaruhi oleh jumlah uang beredar, khususnya jumlah uang beredar dalam arti sempit (M1). Relatif rendahnya inflasi di negara-negara maju, tampaknya disebabkan oleh relatif rendahnya pertambahan jumlah uang beredar, khususnya M1. Tetapi kontrol jumlah uang beredar tidak akan efektif jika tidak didukung oleh kelembagaan keuangan yang sehat dan modern. Lembaga-lembaga inilah yang terus-menerus melakukan inovasi keuangan, khususnya dalam pengembangan instrumen keuangan dan sistem transaksi, yang memungkinkan pasar uang bekerja lebih efisien. Bagi pemerintah, khususnya bank sentral, pasar keuangan yang sudah maju dan efisien ini bermanfaat bagi efektivitas pelaksanaan kebijakan ekonomi, khususnya kebijakan moneter (Manurung dan Rahardja, 2004: 46).

\section{Pengaruh Tingkat Suku Bunga Terhadap Inflasi}

Teori Paradox Gibson menjelaskan bahwa terdapat bukti tentang kecenderungan harga dan tingkat suku bunga bergerak bersama. Jika harga naik, tingkat suku bunga cenderung naik dan jika harga turun, tingkat suku bunga cenderung turun juga.

Kalau perubahan harga diantisipasikan, artinya masyarakat segera berantisipasi terhadap apa yang terjadi, maka tingkat suku bunga yang tinggi akan dikaitkan dengan laju inflasi yang cepat. Akan tetapi tidak ada alasan untuk mengharapkan adanya hubungan positif antara tingkat suku bunga dengan kenaikan laju inflasi, dan sebaliknya penurunan tingkat suku bunga dengan penurunan laju inflasi. Menurut Gibson Paradox, kenaikan harga dikaitkan dengan kenaikan tingkat suku bunga dan penurunan harga dikaitkan dengan penurunan tingkat suku bunga (Iswardono, 1999: 246).

\section{Pengaruh Pengeluaran Pemerintah Terhadap Inflasi}

Tindakan yang perlu dijalankan Bank Sentral adalah untuk mengurangi penawaran uang dan menaikan suku bunga. Kebijakan moneter ini investasi dan rumah tangga (Konsumsi). Seterusnya Kementrian Keuangan perlu pula mengurangi pengeluaran dan menaikan pajak individu dan perusahaa. Langkah tersebut dapat mengurangi pengeluaran pemerintah, mengurangi investasi dan mengurangi pengeluaran rumah tangga. Dengan tindakan ini inflasi dapat diatasi (Sukirno, 349 : 2008).

Secara spesifik, Keynes yakin pemerintah memotong pajak atau menaikkan pengeluarannya yang disebut kebijakan fiskal ekspansioner untuk mengeluarkan perekonomian dari penuruan. Sebaliknya, Keynes mengemukakan bahwa pemerintah hendaknya menaikkan pajak atau mengurangi pengeluarannya yang disebut kebijakan fiskal kontraksioner untuk mengeluarkan perekonomian dari inflasi (Case \& Fair, 1999 : 8). 


\section{METODE PENELITIAN}

\section{Jenis dan Sumber Data}

Jenis data yang digunakan adalah data sekunder, yaitu data yang diperoleh berdasarkan informasi yang telah disusun dan dipublikasikan oleh instansi tertentu. Selain itu data yang digunakan adalah kurun waktu (time series) dari tahun 2006 - 2015.

Data yang diperlukan adalah:

1) Data Tingkat Inflasi di Indonesia tahun $2006-2015$

2) Data Jumlah Uang Beredar di Indonesia tahun 2006 - 2015

3) Data Tingkat Suku Bunga di Indonesia tahun 2006 - 2015

4) Data Pengeluaran Pemerintah di Indonesia tahun 2006 - 2015 meliputi:

Sumber data yang diperoleh melalui dinas/instansi terkait yang berhubungan dengan penelitian

1) Badan Pusat Statistik (BPS) Provinsi Kalimantan Timur.

2) Bank Indonesia Provinsi Kalimantan Timur.

3) Dinas/Instansi lainnya yang terkait dengan penelitian.

\section{Metode Pengumpulan Data}

Metode pengumpulan data merupakan prosedur yang sistematis dan standar guna memperoleh data kuantitatif, di samping itu metode pengumpulan memiliki fungsi teknis guna memungkinkan para penelitian melakukan pengumpulan data sedemikian rupa sehingga angka-angka dapat diberikan pada objek yang diteliti.

Data yang digunakan untuk mencapai tujuan dalam penelitian ini sepenuhnya diperoleh dalam studi pustaka sebagai metode datanya, sehingga tidak digunakan data sekunder. Periode data yang akan digunakan dalam penelitian ini adalah tahun 2006 - 2015. Sebagai pendukung digunakan buku refrensi, jurnal, surat kabar, serta browsing website internet.

\section{Uji Asumsi Klasik}

Proses pengujian asumsi klasik di lakukan bersama dengan proses uji regresi sehingga langkah langkah di lakukan dalam pengujian asumsi klasik menggunakan langkah kerja yang sama dengan uji regresi. Terdapat empat uji asumsi yang harus di lakukan terhadap satu model regresi, yaitu uji autokorelasi, uji multikolinieritas, uji heteroskedastisitas dan uji normalitas.

a. Autokorelasi

Pengujian autokorelasi dilakukan dengan nilai Durbin-Watson (DW). Indikator pengujiannya adalah jika nilai hitung DW berada diluar batas bawah $\left(\mathrm{d}_{\mathrm{L}}\right)$ dan batas atas $\left(\mathrm{d}_{\mathrm{v}}\right)$, maka model tidak tergejala autokorelasi. Nilai hitung DW berada pada kolom terakhir tabel Model Summary ${ }^{b}$ hasil (output) pengerjaan SPSS.

Guna menguji apakah terdapat autokorelasi dilakukan dengan menggunakan metode statistic dari Durbin-Watson, dimana angka DW secara umum dapat diambil patokan:

1) Angka DW dibawah -2 berarti ada autokorelasi positif.

2) Angka DW diantara -2 sampai +2 , berarti tidak ada autokorelasi.

3) Angka DW diatas +2 berarti ada autokorelasi negative.

b. Multikolinearitas

Pengujian multikolinearitas dilakukan dengan mencermati nilai VIF dari model yang dihasilkan oleh output regresi linier berganda. Ukurannya adalah jika nilai VIF di bawah 10 (VIF < 10), maka model tidak tergejala multikolinearitas, nilai VIF pada output SPSS akan tampil pada kolom terakhir Coefficients ${ }^{a}$.

\section{c. Heteroskedastisitas}

Metode analisis grafik dilakukan dengan mengamati scatterplot di mana sumbu horizontal menggambarkan nilai residual studentized. Jika scatterplot membentuk pola tertentu, hal itu menunjukkan adanya masalah heteroskedastisitas pada model regresi yang dibentuk. Sedangkan jika scatterplot menyebar secara acak maka hal itu menunjukkan tidak terjadinya masalah heteroskedastisitas pada model regresi yang dibentuk. 
d. Normalitas

Pengujian normalitas data yang lebih handal adalah dengan melihat normal probability plot yang membandingkan distribusi kumulatif dan distribusi normal. Normalitas dapat dideteksi dengan melihat penyebaran data (titik) pada sumbu diagonal dari grafik Normal P-P Plot. Dasar pengambilan keputusannya adalah:

1) Jika data menyebar di sekitar garis normal dan mengikuti arah garis normalnya, maka model regresi memenuhi asumsi Normalitas.

2) Jika data menyebar jauh dari garis normal dan tidak mengikuti arah garis normalnya, maka model regresi tidak memenuhi asumsi Normalitas.

\section{HASIL DAN PEMBAHASAN}

\section{Penentuan Model Regresi Berganda Fungsi Cobb-Douglas}

Berdasarkan hasil penelitian dengan perhitungan kuantitatif menggunakan model statistik regresi berganda fungsi Cobb-Douglas seperti yang ditunjukkan tabel diatas, sehingga model persamaan regresi sebagai berikut:

$$
\mathrm{Y}=2,131+1,545 \mathrm{X}_{1}+1,838 \mathrm{X}_{2}-1,285 \mathrm{X}_{3}
$$

Bila dimasukkan ke dalam fungsi Cobb-Douglas, maka persamaannya adalah:

$$
\mathrm{Y}=135.2072563 \mathrm{X}_{1}{ }^{1,545} \mathrm{X}_{2}{ }^{1,838} \mathrm{X}_{3}{ }^{-1,285}
$$

\section{Interpretasi dari model:}

1) Nilai konstanta 135.2072563 menunjukkan bila nilai jumlah uang beredar, tingkat suku bungadan pengeluaran pemerintah tidak mengalami perubahan atau tetap maka inflasi di Indonesia akan mengalami peningkatan yaitu sebesar 135.2072563.

2) Jika ada penambahan satu persen pada jumlah uang beredar maka inflasi di Indonesia akan mengalami peningkatan sebesar $1,545 \%$.

3) Jika ada penambahan satu persen tingkat suku bunga maka inflasi di Indonesia akan mengalami peningkatan sebesar $1,838 \%$.

4) Jika ada penambahan satu persen rupiah pengeluaran pemerintah maka inflasi di Indonesia akan mengalami penurunan sebesar $1,285 \%$.

\section{Pembahasan}

\section{Jumlah Uang Beredar Terhadap Inflasi}

Berdasarkan hasil analisis regresi variabel jumlah uang beredar berpengaruh positif dan signifikan terhadap inflasi di Indonesia. inflasi ditentukan oleh pertambahan jumlah uang beredar dan oleh psikologi (harapan) masyarakat mengenai kenaikan harga dimasa yang akan datang. Apabila masyarakat sudah beranggapan demikian, maka tidak ada kecenderungan untuk menyimpan uang tunai lagi dan mereka lebih suka menyimpan harta kekayaan dalam bentuk barang. Hal ini juga sesuai dengan faktor penyebab terjadinya inflasi Demand pull Inflation, yaitu inflasi yang ditimbulkan karena permintaan masyarakat akan berbagai barang terlalu kuat sehingga menaikkan harga - harga secara umum.

Dari fenomena di atas saya dapat simpulkan bahwa permintaan barang yang terlalu kuat disebabkan oleh pendapatan masyarakat yang meningkat, dengan meningkatnya pendapatan jumlah uang beredarpun terlalu banyak beredar di masyarakat sehingga masyarakat dengan mudahnya untuk berbelanja barang-barang dan permintaan barang-barangpun meningkat dan terjadilah inflasi. Maka fenomena ini sesuai dengan hasil penelitian saya yang menyatakan jumlah uang beredar meningkat akan menyebabkan inflasi meningkat.

Hal ini sesuai dengan teori kuantitas, teori ini mengatakan bahwa inflasi bisa terjadi kalau ada penambahan volume jumlah uang. Bila jumlah uang beredar tidak bertambah, inflasi akan berhenti dengan sendirinya, jadi penanggulan inflasi bersumber pada penanggulangan jumlah uang beredar. Jumlah uang beredar bertambah, maka akan terjadi inflasi.

Hasil analisis ini sesuai dengan penelitian terdahulu oleh Adrian dan Zulfahmi (2012) yang berjudul Pengaruh Faktor - Faktor Ekonomi Terhadap Inflasi di Indonesia. Variabel yang diteliti dalam 
penelitian ini adalah tingkat suku bunga, investasi, uang beredar dan nilai tukar. Studi ini menunjukkan bahwa tingkat suku bunga memiliki berpengaruh positif, jumlah uang beredar memiliki pengaruh positif terhadap inflasi, investasi berdampak negative terhadap inflasi dan kurs memiliki dampak positif pada inflasi.

\section{Tingkat Suku Bunga Terhadap Inflasi}

Berdasarkan hasil analisis regresi menunjukkan bahwa variabel tingkat suku bunga berpengaruh positif dan signifikan terhadap inflasi di Indonesia. Pengaruh positif antara tingkat suku bunga dan inflasi mengisyaratkan bahwa kebijakan moneter cenderung mengikuti pergerakan inflasi. Dengan kata lain, kebijakan tersebut bersifat reaktif, kemudian diturunkan apabila tingkat inflasi sudah menunjukan trend penurunan.

Teori keynes mengatakan bahwa tingkat suku bunga yang tinggi akan menurunkan inflasi dikarenakan masyarakat langsung menyimpan uang mereka di bank-bank umum dan berharap mendapatkan bunga dari simpanan mereka tersebut sehingga jumlah uang beredar berkurang dan inflasi ikut turun. Hasil penelitian ini bertentangan dengan teori yang dikemukakan oleh Keynes dimana dalam penelitian ini jika tingkat suku bunga naik maka inflasi juga akan naik, sesuai dengan data yang menunjukkan pada tahun 2008 dan 2013. Pada tahun 2008 tingkat suku bunga naik dari tahun sebelumnya sebesar 9,25 persen dan inflasi juga naik sebesar 11,06 persen. Sedangkan pada tahun 2013 tingkat suku bunga naik menjadi 7,5 persen inflasi naik menjadi 8,38 persen. Hal ini sesuai dengan teori Paradox Gibson yang menjelaskan bahwa apabila harga mengalami kenaikan, tingkat suku bunga cenderung naik. Sebaliknya, bila harga mengalami penurunan, maka tingkat suku bunga juga cenderung turun.

Inflasi di impor adalah Inflasi yang berasal dari luar negeri yang timbul karena negara - negara yang menjadi mitra dagang negara tertentu mengalami inflasi yang tinggi. Kenaikan harga-harga di luar negeri yang menjadi mitra dagang utama yang secara langsung ataupun tidak langsung akan menaikkan biaya produksi dalam negeri. Kenaikan ini akan menaikkan harga-harga barang.

Hasil analisis ini sesuai dengan penelitian terdahulu oleh Adrian dan Zulfahmi (2012) yang berjudul Pengaruh Faktor - Faktor Ekonomi Terhadap Inflasi di Indonesia. Variabel yang diteliti dalam penelitian ini adalah tingkat suku bunga, investasi, uang beredar dan nilai tukar. Studi ini menunjukkan bahwa tingkat suku bunga memiliki berpengaruh positif, jumlah uang beredar memiliki pengaruh positif terhadap inflasi, investasi berdampak negative terhadap inflasi dan kurs memiliki dampak positif pada inflasi.

\section{Pengeluaran Pemerintah Terhadap Inflasi}

Berdasarkan hasil analisis regresi menunjukkan bahwa variabel pengeluaran pemerintah berpengaruh negative dan signifikan terhadap inflasi di Indonesia. Hal ini disebabkan oleh pemerintah mengambil kebijakan fiskal berupa tindakan memperkecil pengeluaran pemerintah, dengan menunda proyek - proyek pemerintah yang telah direncanakan sebelumnya. Kebijakan fiskal lainnya adalah dengan mengurangi transfer pemerintah, yang dimaksud transfer pemerintah adalah pengeluaran tanpa balas jasa langsung, misalnya bantuan bencana alam, beasiswa pelajar, bantuan kepada rakyat miskin dan subsidi. Dengan mengurangi transfer pemerintah maka laju pertambahan uang yang beredar di masyarakat dapat dikendalikan sehingga inflasi dapat dikurangi, hal ini sesuai dengan teori Keynes yang mengatakan ada tiga bentuk kebijakan pemerintah dapat digunakan untuk mencapai tujuan - tujuan kebijakan makro ekonomi yaitu:

Kebijakan fiskal, kebijakan moneter dan pengawasan langsung. Kebijakan fiskal dijalankan oleh Departemen Keuangan dan alat yang digunakan adalah melalui pengaturan anggaran pengeluaran dan penerimaan pemerintah (perpajakan). Dalam masa inflasi biasanya kebijakan fiskal akan berbentuk mengurangi pengeluaran pemerintah dan meningkatkan pajak.

Secara spesifik, Keynes yakin pemerintah memotong pajak atau menaikkan pengeluarannya yang disebut kebijakan fiskal ekspansioner untuk mengeluarkan perekonomian dari penuruan. Sebaliknya, Keynes mengemukakan bahwa pemerintah hendaknya menaikkan pajak atau mengurangi pengeluarannya yang disebut kebijakan fiskal kontraksioner untuk mengeluarkan perekonomian dari inflasi. 
Berkurangnya pengeluaran pemerintah menyebabkan jumlah uang yang akan beredar di mayarakat berkurang dan dengan menaikkan pajak berarti penghasilan seseorang akan berkurang karena sebagian dari penghasilannya itu dalam bentuk pajak telah di berikan kepada pemerintah. Artinya, pendapatan disposibel berkurang yang pada gilirannya menyebabkan daya beli masyarakat juga akan berkurang. Keadaan ini menyebabkan harga-harga barang tidak naik lagi sehingga demand pull inflation dapat dikendalikan dan inflasi akan turun.

Hasil analisis ini sesuai dengan penelitian terdahulu Edy Syahputra Sitepu yang berjudul Analisis Inflasi Sumatera Utara 1980 - 2000. Hasil penelitian menemukan bahwa inflasi sumut di pengaruhi oleh pengeluaran pemerintah berpengaruh negative, investasi berpengaruh positif, jumlah kredit yang disalurkan bank umum berpengaruh positif, ekspor neto berpengaruh positif, kurs berpengaruh positif dan ekspetasi masyarakat berpengaruh positif. Dari sejumlah variabel tersebut, secara umum hasil estimasi memperlihatkan bahwa total pengeluaran pemerintah, kredit yang disalurkan oleh bank - bank umum, ekspor neto, dan kurs mempunyai pengaruh yang signifikan terhadap perkembangan inflasi di Sumatera Utara.

\section{SIMPULAN}

Berdasarkan analisis dan pembahasan yang telah di uraikan sebelumnya, maka penulis dapat menarik beberapa kesimpulan sebagai berikut:

1. Jumlah uang beredar berpengaruh positif dan signifikan terhadap inflasi di Indonesia. Pengaruh positif antara jumlah uang beredar dan inflasi disebabkan oleh Demand pull Inflation, yaitu inflasi yang ditimbulkan karena permintaan masyarakat akan berbagai barang terlalu kuat sehingga menaikkan harga - harga secara umum. Permintaan barang terlalu kuat disebabkan oleh pendapatan masyrakat yang meningkat, dengan meningkatnya pendapatan jumlah uang beredarpun terlalu banyak beredar di masyrakat sehingga masyarakat dengan mudahnya untuk berbelanja barangbarang dan permintaan barang-barangpun meningkat dan terjadilah inflasi.

2. Tingkat suku bunga berpengaruh positif dan signifikan terhadap inflasi di Indonesia. Pengaruh positif antara tingkat suku bunga dan inflasi mengisyaratkan bahwa kebijakan moneter cenderung mengikuti pergerakan inflasi. Dengan kata lain, kebijakan tersebut bersifat reaktif, kemudian diturunkan apabila tingkat inflasi sudah menunjukan trend penurunan. Tingkat suku bunga yang tinggi tidak selamanya bisa menurunkan inflasi karena di Indonesia inflasi bisa disebabkan oleh negara-negara luar karena Indonesia menganut perekonomian terbuka. Hal ini juga sesuai dengan faktor-faktor terjadinya inflasi yaitu inflasi di impor.

3. Pengeluaran pemerintah berpengaruh negative dan signifikan terhadap inflasi di Indonesia. Pengaruh negative disebabkan oleh pemerintah mengambil kebijakan fiskal berupa tindakan memperkecil pengeluaran pemerintah. Berkurangnya pengeluaran pemerintah menyebabkan jumlah uang yang akan beredar di mayarakat berkurang dan dengan menaikkan pajak berarti penghasilan seseorang akan berkurang karena sebagian dari penghasilannya itu dalam bentuk pajak telah di berikan kepada pemerintah. Artinya, pendapatan disposibel berkurang yang pada gilirannya menyebabkan daya beli masyarakat juga akan berkurang. Keadaan ini menyebabkan harga-harga barang tidak naik lagi sehingga demand pull inflation dapat dikendalikan dan inflasi akan turun.

\section{DAFTAR PUSTAKA}

Bambang.1991. Statistik. BPFE. Yogyakarta

Boediono. 2005. Ekonomi Moneter. BPFE. Yogyakarta

Gani, Amalia. 2014. Alat Analisis Data. Andi. Yogyakarta

Ghozali, Imam. 2004. Aplikasi Analisis Multivarite Dengan Program SPSS. Badan Penerbit Universitas Diponegoro. Semarang

Gujarati, Damodar. 2005. Ekonometrika Dasar Terjemahan Sumarmo Zain. Erlangga. Jakarta

Hasan, Iqbal, 2001. Pokok-pokok Materi Statistik 2. PT Bumi Aksara. Jakarta

Hasan, Iqbal, 2004. Analisis Data Penelitian Dengan Statistik. Bumi Aksara Jakarta

Iswardono. 1996. Uang dan Bank. BPFE UGM: Yogyakarta

Koentjraningrat. 2001. Metode-metode Penelitian Masyarakat. PT Gramedia Pustaka Utama. Jakarta

Mankiw, N. Gregory. 2003. Pengantar Ekonomi. Erlangga. Jakarta 
Volume $19(2), 2017$

2003, Teori Makro Ekonomi. Erlangga. Jakarta

Manurung, Rahardja.2004. Uang, Perbankan, dan Ekonomi Moneter. Fakultas Ekonomi Universitas Indonesia. Jakarta

Malayu, Hasibuan. 2004. Dasar - Dasar Perbankan. Bumi Aksara. Jakarta

McEachern, William A. 2000, Ekonomi Makro. Salemba Empat. Jakarta

Narbuko, Cholid. 2010. Metodologi Penelitian. Bumi Aksara. Jakarta.

Nasution, Mulia. 2001. Ekonomi Moneter. Djambatan. Jakarta

Nopirin, 1995.Ekonomi Moneter bukudua. BPFE. Yogyakarta

Prakasiwi, Yani A. 2009. Pengaruh Jumlah Uang Yang Beredar dan Tingkat Suku Bunga Terhadap Inflasi di Indonesia. Fakultas Ekonomi Universitas Mulawarman. Samarinda

Rimsky. 2002. Sistem Moneter Perbankan di Indonesia. PT. Gramedia Pustaka Utama. Jakarta

Siagian, Dergibson, et.all. 2002. Metode Statistika Untuk Bisnis dan Ekonomi. PT. Gramedia Pustaka Utama. Jakarta

Sitepu, Sahputra. Analisis Inflasi Sumatera Utara 1980-2000

Sukirno, Sadono. 2000. Makroekonomi Modern. Rajawali Pers. Jakarta

Sugiyanto, Catur. 2002.Ekonomi Terapan. BPFE. Yogyakarta

Sugiyono. 2008. Statistika untuk Penelitian. Alfabeta. Bandung

Suliyanto. 2011. Ekonometrika Terapan Teori \& Aplikasi. Andi. Yogyakarta

Suparmoko M. Dan Maria R. Suparmoko. 2000. Pokok-pokok Ekonometrika. BPFE. Yogyakarta

Supranto J. 2000. Statistik Teori dan Aplikasi edisi keenam. Erlangga, Jakarta

Sutawijya dan Zulfahmi. 2012. Pengaruh Faktor-Faktor Ekonomi Terhadap Inflasi di Indonesia.

Fakultas Ekonomi Universitas Terbuka

Waluyo, Eko. 2006. Ekonomika Makro. UMM PRESS. Malang

Zulfikar, Lufi A. 2017. Pengaruh Jumlah Uang Beredar dan Tingkat Suku Bunga Terhadap Inflasi Kalimantan Timur. Fakultas Ekonomi dan Bisnis Universitas Mulawarman. Samarinda

Zuriah, Nurul. 2006. Metodologi Penelitian Sosial dan Pendidikan. Bumi Aksara. Jakarta

http://www.Bps.go.id (diakses tgl 11 September 2016)

http://www.bi.go.id (diakses tgl 28 September 2016) 